\title{
Severe metformin intoxication in an adolescent: A case report
}

\author{
Dana Adriana Dascultu, Elena Madalina Petran \\ "Grigore Alexandrescu" Emergency Hospital for Children, Bucharest, Romania
}

\begin{abstract}
Introduction. The frequency of acute metformin intoxication is increasing with increasing availability and accessibility of children and adolescents to this oral antidiabetic. Acute metformin intoxication can be severe and evolve to multiple organ failure.

Case report. A 16-year old teenager is transfered from another hospital to the Toxicology and Intensive Care unit of "Grigore Alexandrescu" Emergency Hospital for Children, in Bucharest, for somnolence and vomiting after she has voluntarily taken 10 tablets of Siofor (Metformin). Laboratory findings on admission detected the presence of metabolic acidosis $(\mathrm{pH}=7.28, \mathrm{~EB}=-9.4 \mathrm{mmol} / \mathrm{l}, \mathrm{HCO} 3=14.2 \mathrm{mmol} / \mathrm{l}$, lactate $=4.06 \mathrm{mg} / \mathrm{dl})$, and kidney function testes revelead an increased value of creatinine $1.57 \mathrm{mg} / \mathrm{dl}$. Initial treatment included sodium bicarbonate and endovenous glucose and electrolytes without improvment in the clinical status of the patient who evolved with severe lactic acidosis $(\mathrm{pH}=7.19$, lactate $=5.5 \mathrm{mg} / \mathrm{dl}, \mathrm{HCO} 3=18 \mathrm{mmo} / \mathrm{l})$, acute renal failure (urea $=59 \mathrm{mg} / \mathrm{dl}$, creatinine $=4.06 \mathrm{mg} / \mathrm{dl}$ ). She was transfered to the nephrology unit of another hospital to perform emergency hemodialysis. The patient subsequently underwenth two hemodialysis session, following dialysis normal renal function and full recovery was obtained.

Conclusions. Acute metformin poisoning can be severe and lead to death if unrecognized, monitored and treated rapidly. Lactic acidosis imposes rapid and effective suportive treatment measures or renal replacement therapy.
\end{abstract}

Keywords: metformin, acute intoxication, teenager, lactic acidosis, hemodialysis

\section{INTRODUCTION}

Acute poisonings in children are more frequent, studies showing that they account for aproximately $20 \%$ of all admission in the hospital in developing countries. In Romania, $10 \%$ of all cases of poisoning are in children, and the most common etiology is drugs (1).

Metformin is a biguanide, a class of oral antidiabetic, used as a first line therapy for the treatment of type 2 diabetes mellitus. It's a hidrosoluble molecule, minimally protein bound, with rapid distribution and intestinal absorption. It has a 4-8.7 h half time, with no liver transformation, no biliary removal, its clearance depends exclusivly on renal removal. Metformin acts by decreasing hepatic gluconeogenesis, reducing absorption of glucose in the gastrointestinal tract and increasing glucose utilization in periferic tissues, all these leading to reduce glucose plasma levels (2).

Simptoms associated with metformin poisoning are predominantly gastrointestinal: nausea, vomiting, abdominal pain (3). Severe cases of metformin intoxication can lead to development of lactic acidosis and acute renal and liver failure. The mechanism of lactic acidosis developing is not fully understood, some studies show that it may be secondary to inhibition of complex I of the mitochondrial respiratory chain (4). Metformin activates AMP-protein-kinase (AMPK), which is a sensor of the sistemic and cellular energetic load. AMPK is a heterotrimer protein consisting an alfa catalitic subunit and two reglatory gamma subunits. AMPK is a key regulator of energy dynamics by inhibition of anabolic pathways and facilitating catabolic pathways, to increase ATP production. Lactic acidosis is a anion gap metabolic acidosis with lactate concentration greater than $5 \mathrm{mmol} / \mathrm{l}$. Hyperlactatemia is a marker frequently seen in poisoned patients, and is used in assesing potential severe outcome(5).

We present a case of deliberate metformin overdose in a teenager as this poisoning is becoming more frequent in this group age.

\section{CASE PRESENTATION}

A 16-year old teenager is transfered from another medical facility to the Toxicology and Intensive Care 
unit of "Grigore Alexandrescu" Emergency Children Hospital, in Bucharest, for somnolence and vomiting after she has voluntarily taken 10 tablets of Siofor (Metformin), tablets of $1,000 \mathrm{mg}$ each. The reported time of ingestion was 12 hours prior to arrival in our clinic. 4 hours after the onset of simptoms she was transported to the nearest hospital, where gastric decontamination procedures where applied and she was administered activated charcoal and endovenous glucose and electrolytes then transfered in our clinic. Medical history showed no prior chronic diseases or chronic treatment.

At admission in our clinic, she was with altered general condition, no fever, somnolent, cold extremities. Vital signs were: oxygen saturation $98 \%$ on room air, pulse 90 beats per minute, blood pressure 121/84 $\mathrm{mmHg}$, normal breathe sounds, vomiting, no tenderness on abdominal examination, equal reactive pupils, no signs of meningeal iritation.

Laboratory findings on admission in our clinic shown the presence of metabolic acidosis $\mathrm{pH}=7.28$, $\mathrm{EB}=-9.4 \mathrm{mmol} / 1, \mathrm{HCO} 3=14.2 \mathrm{mmol} / \mathrm{l}$, lactate $=3.5$ $\mathrm{mmol} / \mathrm{l}$, and renal function revealed an increased creatinine value $1.57 \mathrm{mg} / \mathrm{dl}$, liver function and $\mathrm{CBC}$ count where within normal range. Abdominal ultrasound was performed and showed enlarged kidneys, with pyelocaliceal dilation and important decrease in corticomedullary differentiation.

Initial treatment was with endovenous glucose and electrolytes and sodium bicarbonate $8.4 \%$ and constant monitoring of vital signs, glycemia, renal and hepatic function and basic metabolic panel values.

24 hours after admission, the patients presented altered neurological status, somnolence and laboratory findings revealed persistence in kidney function abnormalities: urea $=59 \mathrm{mg} / \mathrm{dl}$, creatinine $=4.06 \mathrm{mg} / \mathrm{dl}$. All these findings consisting with the abdominal ultrasound abnormalities lead to the decision to transfer the patient to the Nephrology department of "M.S. Curie" Emergency Hospital for Children in Bucharest to initiate renal replacement therapy. Table 1 shows laboratory findings in dynamics.

TABLE 1. Evolution of laboratory findings

\begin{tabular}{|l|c|c|c|}
\hline & $\begin{array}{c}\text { Patient's } \\
\text { values on } \\
\text { admission }\end{array}$ & $\begin{array}{c}\text { Patient's } \\
\text { values } \\
24 \text { h post- } \\
\text { admission }\end{array}$ & $\begin{array}{c}\text { Normal } \\
\text { values }\end{array}$ \\
\hline $\mathrm{pH}$ & 7.28 & 7.19 & $7.35-7.45$ \\
\hline $\begin{array}{l}\text { Base excess } \\
\text { (mmol/l) }\end{array}$ & -9.4 & -11.4 & $-3-3$ \\
\hline $\begin{array}{l}\text { Bicarbonate } \\
\text { (mmol/l) }\end{array}$ & 14.2 & 16 & $18-23$ \\
\hline Lactate (mmol/l) & 3.5 & 5.5 & $0.5-1.5$ \\
\hline
\end{tabular}

\begin{tabular}{|c|c|c|c|}
\hline & $\begin{array}{l}\text { Patient's } \\
\text { values on } \\
\text { admission }\end{array}$ & $\begin{array}{l}\text { Patient's } \\
\text { values } \\
24 \mathrm{~h} \text { post- } \\
\text { admission }\end{array}$ & $\begin{array}{l}\text { Normal } \\
\text { values }\end{array}$ \\
\hline $\operatorname{ALT}(\mathrm{U} / \mathrm{I})$ & 19 & 20 & $5-34$ \\
\hline AST (U/I) & 20 & 21 & $0-31$ \\
\hline Urea (mg/dl) & 25 & 59 & $17-43$ \\
\hline Creatinine $(\mathrm{mg} / \mathrm{dl}$ & 1,57 & 4,06 & $0.65-1.1$ \\
\hline Glycemia (mg/dl) & 95 & 79 & $70-105$ \\
\hline Sodium (mmol/l) & 145 & 136 & $136-146$ \\
\hline Potassium (mmol/l) & 4,12 & 4,09 & 3.4-4.5 \\
\hline Chloride (mmol/l) & 103 & 96 & $98-106$ \\
\hline Total protein $(\mathrm{g} / \mathrm{dl})$ & 7,78 & 6,81 & $6.6-8.7$ \\
\hline Hemoglobin (g/dl) & 11.2 & 10,6 & $12-15$ \\
\hline Platelets $\left(/ 10^{3} / \mathrm{ul}\right)$ & 229,000 & 202,000 & $150.0-400.0$ \\
\hline $\begin{array}{l}\text { White blood cell } \\
\text { count }\left(/ 10^{3} / \mathrm{ul}\right)\end{array}$ & 24,100 & 12,260 & $4.8-10.8$ \\
\hline
\end{tabular}

ALT - alanin aminotrasferase, AST - aspartat aminotransferase

After the admission in the nephrology department, a double lumen catheter is place in the right jugular vein and first hemodialysis session is initiated. 48 hours after the initiation of hemodialysis, the patients renal function tests and basic metabolic panel values normalized. Table 2 shows modification in laboratory findings during hemodialysis.

TABLE 2. Hemodialysis response

\begin{tabular}{|l|c|c|c|c|}
\hline Parameters & $\begin{array}{c}\text { After I } \\
\text { hemo- } \\
\text { dialysis } \\
\text { session }\end{array}$ & $\begin{array}{c}\text { Before II } \\
\text { hemo- } \\
\text { dialysis } \\
\text { session }\end{array}$ & $\begin{array}{c}\text { After II } \\
\text { hemo- } \\
\text { dialysis } \\
\text { session }\end{array}$ & $\begin{array}{c}\text { Normal } \\
\text { values }\end{array}$ \\
\hline $\mathrm{pH}$ & 7.31 & 7.32 & 7.41 & $7.35-7.45$ \\
\hline $\begin{array}{l}\text { Base excess } \\
\text { (mmol/l) }\end{array}$ & 4.4 & 3 & 2.2 & $-3-+3$ \\
\hline $\begin{array}{l}\text { Bicarbonate } \\
\text { (mmol/l) }\end{array}$ & 26.2 & 24 & 23 & $18-23$ \\
\hline $\begin{array}{l}\text { Lactate } \\
\text { (mmol/l) }\end{array}$ & 4 & 2,2 & 1 & 0.7 \\
\hline $\begin{array}{l}\text { Creatinine } \\
\text { (mg/dl) }\end{array}$ & 1.88 & 1.4 & 0.7 & $0.65-1.1$ \\
\hline $\begin{array}{l}\text { Urea (mg/ } \\
\text { dl) }\end{array}$ & 22 & & 20 & $17-43$ \\
\hline $\begin{array}{l}\text { Anion gap } \\
\text { (mEq/l) }\end{array}$ & 16.9 & & 20 & $3-11$ \\
\hline
\end{tabular}

9 days after ingestion, the patient was discharged from the nephrology department in good general health condition, vital signs as follows: no fever, normal breathe sounds, pulse 85 beats per minute, blood pressure 101/63 mmHg. A recommendation for psychological and psychiatric evaluation was made. Laboratory findings on discharge revealed normal values for renal function: urea $=45 \mathrm{mg} / \mathrm{dl}$, creatinine $=0.61$ $\mathrm{mg} / \mathrm{dl}, \mathrm{pH}=7.41, \mathrm{~EB}=0.2 \mathrm{mmol} / \mathrm{l}, \mathrm{HCO} 3=20$ $\mathrm{mmol} / \mathrm{l}$. 


\section{DISCUSSION}

We presented the case of an severe acute metformin poisoning in a teenager due to the increasing frequency of this etiology in pediatric population.

In literature are few metformin cases of poisoning in children reported, the first case was presented by Lacher et al.: a 15 years-old teenager who ingested in a suicide attempt $38.25 \mathrm{~g}$ of metformin evolving to lactic acidosis and renal failure (6). Another multicentre study analized 37 cases of pediatric metformin ingestion with doses ranging from $250 \mathrm{mg}$ to $16.5 \mathrm{~g}$. None of these children developed hypoglycemia or lactic acidosis (7). Cases of metformin poisonig developing lactic acidosis are rare, but most of them have fatal outcome despite the evolved means of therapy (8). There are 2 categories of lactic acidosis according with Cohen-Woods classification: type A associated with poor tissue perfusion, and type B defined as lack of tissue hypoperfusion. Dell'Aglio DM et al. reported the case of a patient who ingested aproximatly 75-100 grams of metformin, the largest reported amount of metformin ingested described in literature, who developed severe lactic acidosis $\mathrm{pH}=6.59$ and lactate value $40 \mathrm{mmol} / \mathrm{l}$. After hemodialysis was initiated, the patient made a complete recovery without any residual sequelae (9).

Signs and symptoms associated with metformin poisoning are not specific and include: nausea, anorexia, vomiting, abdominal pain, lethargy, somnolence, hyperpnea. It may evolve with: hypotension, hypoglycemia, pancreatitis, hypothermia, lactic acidosis, renal and liver failure, coma, and cardiac arrest (3). Studies have failed in showing an association between the outcome and lactate concentration and metformin dose (10). Our case presented with gastrointestinal symptoms, neurological signs and lactic acidosis and evolved with renal failure. Even since admission, the $\mathrm{pH}$, bicarbonate and lactate indicated lactic acidosis. Monitoring renal function indicated increasing values of urea and creatinine, so renal replacement therapy was started.

Metformin acute poisoning treatment is primarly supportive, including measures for gastric decontamination to limit intestinal absorption of the drug by using activated charcoal and the correction of metabolic imbalances. Sodium bicarbonate can be a therapeutic alternative to correct metabolic imbalances but caution on utilization because it can complicate with: left shift of the oxyhaemoglobin dissociation curve, sodium load, rebound metabolic alkalosis, disturbances in potassium and calcium levels, and reflex vasodilatation (11).
Treatment failure using conservative measures directs therapy towards renal replacement techniques. The first choice in therapy is hemodialysis, which corrects refractary acidosis, removes lactate, pyruvate and ketones, as it is supportive therapy for uremia (12). EXTRIP recommendations for extracorporeal treatments are as follows: lactate concentration greater than $20 \mathrm{mmol} / \mathrm{l}$, pH less than 7, shock, decreased level of consciousness, failure of supportive standard measures. Extracorporeal treatment should be continued until the lactate concentration is less than 3 $\mathrm{mmol} / \mathrm{l}, \mathrm{pH}$ value is 7.35 . The initial recommendation is for intermitent hemodialysis but if is not available continous renal replacement therapy should be considered (13).

Metformin pharmacokinetics contributes to its ability to be eliminated by dialysis techniques, mandatory for maximum efficacy being rapid initiation, due to metformin larger distribution volume (14). There are studies that, based on metformin's bicompartmental distribution, recommend continous renal replacement therapy as first choice and shows a $60 \%$ elimination of the drug according with the values measured prior and post-therapy (15).

In our case, the patient received treatment early on the onset of symptoms, with activated charcoal in the attempt to limit metformin's intestinal absorption, and saline solution to prevent dehydration. During her stay in the hospital in Toxicology and Intensive Care unit, was administered sodium bicarbonate and endovenous glucose and electrolytes. The initial supportive measures did not correct lactate and metabolic panel values, patient evolving towards acute renal failure as shown by the increased values of urea and creatinine and abdominal ultrasound renal abnormalities. The decision to start renal replacement therapy led to the transfer of the patient to another hospital's nephrology department. After the first hemodialysis session, the laboratory findings revealed still increased levels for creatinine and metabolic acidosis persistence wich led to the initiation of a second hemodialysis session. Monitoring renal function and metabolic panel values after second hemodialysis session showed values within normal range, then the decision to stop renal replacement therapy was made. Once hemodialysis was started in dynamics, normal renal function and full recovery was obtained.

The particularity of this case is represented by its evolution with altered mental status associated with acute renal failure in the presence of high levels of lactate which imposed the decision of initiating hemodialysis. So in case of metformin poisoning, monitoring renal function tests should be done, to prevent evolving with acute renal failure. 


\section{CONCLUSIONS}

Acute metformin poisoning can be severe, leading to death, thus it must be recognized, monitorized and treated as fast as possible. Symptoms associated with metformin intoxication are predominantly gastrointestinal, with the posibility to evolve with neurologi-

\section{REFERENCES}

1. Ulmeanu $C$, Nițescu V, Ulmeanu A. Intoxicațiile acute la copil și adolescent. Oltenița: Tridona, 2015.

2. Bailey CJ, Turner RC. Metformin. N Engl J Med. 1996 Feb 29;334(9):574-9.

3. Spiller HA, Quadrani DA. Toxic effects from metformin exposure. Ann Pharmacother. 2004;38(5):776-80.

4. Chu CK, Chang YT, Lee BJ, Hu SY, Hu WH, Yang DY. Metforminassociated Lactic Acidosis and Acute Renal Failure in a Type 2 Diabetic Patient. J Chin Med Assoc. 2003;66(8):505-8.

5. Luft FC. Lactic acidosis update for critical care clinicians. J Am Soc Nephrol. 2001;12(Suppl 17):S15-9.

6. Lacher M, Hermanns-Clausen M, Haeffner K, Brandis M., Pohl M. Severe Metformin Intoxication With Lactic Acidosis in an Adolescent. Eur J Pediatr. 2005;164(6):362-5.

7. Spiller HA, Weber JA, Winter ML, Klein-Schwartz W, Hofman M, Gorman SE et al. Multicenter Case Series of Pediatric Metformin Ingestion. Ann Pharmacother. 2000;34(12):1385-8.

8. Peters N, Jay N, Barraud D, Cravoisy A, Nace L et al. Metformin-associated lactic acidosis in an intensive care unit. Crit Care. 2008; 12(6):R149. cal and multiorgan failure. Lactic acidosis associated with metformin poisoning needs initiation of supportive treatment measures as those of renal replacement therapy due to its potential fatal outcome.

\section{Acknowledgement}

Both authors contributed equally to this article.

Conflict of interest: none declared Financial support: none declared

9. Dell'Aglio DM, Perino LJ, Todino JD, Algren DA, Morgan BW. Metformin overdose with a resultant serum $\mathrm{pH}$ of 6.59: Survival without sequalae. J Emerg Med. 2010;39(1):e77-e80.

10. Manini AF, Kumar A, Olsen D, Vlahov D, Hoffman RS. Utility of Serum Lactate to Predict Drug-Overdose Fatality. Clin Toxicol (Phila). 2010;48(7):730-6.

11. Ryder RE. The Danger of High Dose Sodium Bicarbonate in Biguanide-Induced Lactic Acidosis: The Theory, the Practice and Alternative Therapies. Br J Clin Pract. 1987;41(5):730-7.

12. Barrueto F, Meggs WJ, Barchman MJ. Clearance of Metformin by Hemofiltration in Overdose. J Toxicol Clin Toxicol. 2002;40(2):177-80.

13. Calello DP, Liu KD, Wiegand TJ et al. Extracorporeal Treatment for Metformin Poisoning: Systematic Review and Recommendations From the Extracorporeal Treatments in Poisoning Workgroup. Crit Care Med. 2015;43(8):1716-30.

14. Guo PYF, Storsley LJ, Finkle SN. Severe Lactic Acidosis Treated With Prolonged Hemodialysis: Recovery After Massive Overdoses of Metformin. Semin Dial. 2006;19(1):80-3.

15. Lalau JD, Andrejak M, Morinière $P$ et al. Hemodialysis in the Treatment of Lactic Acidosis in Diabetics Treated by Metformin: A Study of Metformin Elimination. Int J Clin Pharmacol Ther Toxicol. 1989;27(6):285-8. 